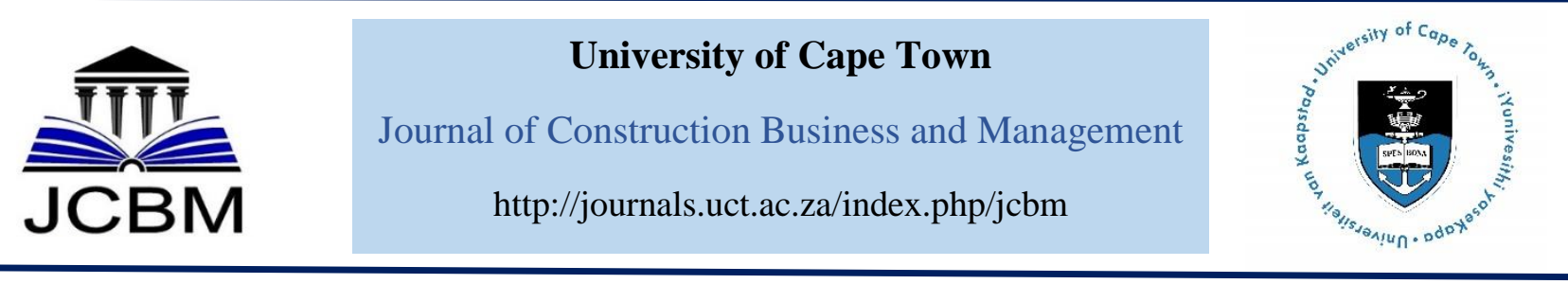

\title{
A Bespoke Approach for Relating Material Waste to Cost Overrun in the Construction Industry
}

\author{
I. Saidu ${ }^{1}$, W. M. Shakantu², A. D. Adamu³, I.C. Anugwo ${ }^{4}$ \\ Department of Construction Management, Nelson Mandela Metropolitan University, South Africa. ${ }^{1,2,3,4}$
}

Received 9 November 2016; received in revised form 16 January 2017, 2 March 2017 and 5 March 2017; accepted 15 March 2017

\begin{abstract}
The problems of material waste and cost overruns are common in the construction industry. These problems occur at different stages of a construction project, from planning, design to project execution. The argument on how to eliminate cost overruns has been on-going for the past 70 years as on-site wastage of materials leads to increase in the final project cost. This paper examines the relationship between the causes of material waste and those of cost overrun at the pre-contract and post-contract stages of a project. Literature review revealed that all $(100 \%)$ the causative factors for material waste at the pre-contract and post-contract stages of a project are linked to $96.88 \%$ and $81.36 \%$ of the causes of cost overruns at these stages respectively. The results were further validated by interviews conducted with 30 construction professionals using purposive sampling method within Abuja, Nigeria. Other causes of cost overruns which are not related to those of material waste are mostly the micro-economic and macro-economic factors. It was also found that to achieve Effective Construction Material Waste Management (ECMWM) for any construction project, the causes of material waste must be controlled at its sources and causes, and at different stages of a project. The implication of these findings is that project cost overrun can be effectively controlled by curbing the causes of material waste.
\end{abstract}

Keywords: Construction industry; Cost overruns; Construction waste; Material waste.

\section{Introduction}

The construction industry remained one of the driving forces behind the socio-economic development of any nation. However, it is faced with severe problems of cost overruns and construction waste (Abdul-Rahman et al., 2013; Osmani et al., 2008; Nagapan et al., 2012a; Saidu and Shakantu, 2016a). Material wastage has become a serious problem, which requires urgent attention in the construction industry (Adewuyi and Otali, 2013). The majority of this waste has not been well managed, thus causing substantial health and environmental problems (Imam et al., 2008), and affecting the performance of many projects (Adewuyi and Otali, 2013; Ameh and Itodo, 2013; Oladiran, 2009; Saidu and Shakantu, 2016b). This problem is disclosed by various authors reporting on the situation, for instance, $28.34 \%$ of the total waste sent to landfills in Malaysia originates from construction activities (Begum et al., 2007); the US generates 164million tonne of construction waste annually representing $30-40 \%$ of the country's Municipal Solid Waste (MSW) (Osmani, 2011); China alone generates $30 \%$ of the world's MSW, out of which construction and demolition waste represents $40 \%$ of the country's MSW (Lu and Yuan, 2010); 10\% of the materials delivered to sites in the United Kingdom (UK) construction industry end up as waste that may not be accounted for (Osmani, 2011); and Ameh and Itodo (2013) noted that for every 100 houses built, there is sufficient waste materials to build another 10 houses in Nigeria.

Similarly, cost overrun is a common problem in both developed and developing countries (Memon et al., 2013).

\footnotetext{
${ }^{1}$ Corresponding Author. +27810916224.

Email address: s214344924@nmmu.ac.za

${ }^{2}$ Email address: winston.shakantu@nmmu.ac.za

${ }^{3}$ Email address: ninadzi@ futminna.edu.ng

${ }^{4}$ Email address: saidu.ibr@futminna.edu.ng
} 
For instance, $33.3 \%$ of construction project owners in the UK are faced with the problems of cost overrun (AbdulRahman et al., 2013). Cost overrun is associated with projects across twenty nations and five continents of the world (Allahaim and Liu, 2012; Flyvbjerg et al., 2004). The argument on how to reduce or totally remove cost overruns from projects has been on-going among major stakeholders in the construction industry for the past seventy years (Apolot et al., 2010; Allahaim and Liu, 2012), but there is neither substantial improvement nor significant solution in mitigating its detrimental effects (Allahaim and Liu, 2012); and it is logical to reason that on-site wastage of material leads to increase in the final cost of a building project because, as materials are wasted, more will be required, thereby affecting the estimated cost of the project (Ameh and Itodo, 2013). This is regardless of the 5\% contingency allowance to cover material wastage in the bills of quantities in countries like Nigeria. Therefore, the problems of material waste and cost overrun are occasioned by several causes at different stages of projects. These include: the planning stage, estimating stage, design and design management stage, as well as the construction stage. Identification of these causes at different stages and the application of relevant control measures to minimise their occurrence is a step towards alleviating the consequences (Mou, 2008; Oladiran, 2009; Nagapan et al., 2012b; Saidu and Shakantu, 2015). Ameh and Itodo (2013) assert that most managers of construction projects pay little attention to the effects of material waste generated on cost overrun. Many studies have been conducted in this field, for instance, Tam et al. (2007) assessed the levels of material wastage affected by sub-contracting relationships and projects types with their correlations on construction site; Ameh and Itodo (2013) assessed professionals' views of material wastage on construction sites and cost overruns. The study adopted a survey (questionnaire) research approach which is considered a subjective assessment. Saidu and Shakantu (2015) examined the relationship between quality of estimating, construction material waste generation and cost overruns in Abuja, Nigeria; Saidu and Shakantu (2016a) examined the relationship between material waste and cost overrun in the construction industry using literature based methodology and recommended further empirical investigations. Moreover, Saidu and Shakantu (2016b) developed a framework and an equation for managing constructionmaterial waste and cost overruns but these are not empirically inclined. These therefore, provides the need for a research that provides a holistic assessment of the relationship between the causes of material waste and those of cost overrun at pre-contract and post-contract stage of a construction project. Hence, this paper examines the relationship between the causes of material waste and those of cost overruns with a view to suggesting the possible ways of minimising their effects at the precontract and the post-contract stage of a project. To achieve this, the following objectives were formulated: To identify the material waste causes that have effects on cost overruns at pre-contract and post-contract stages of a project; and to determine material waste control measures that have effects in controlling cost overruns at the precontract and at the post contract stages of a project.

\section{Literature Review}

\subsection{Construction Waste}

Construction waste is a global challenge faced by construction practitioners. It can have a significant impact on time, cost, quality and sustainability (Saidu, 2016).

Construction waste is generally classified into two, namely: the physical waste (the waste that could be physically seen and touched) and the non-physical waste (Nagapan et al., 2012b).

\subsubsection{Physical Construction Waste}

Physical construction waste is the waste from construction and renovation activities, including building and civil engineering works. It is however, referred by some directly as solid waste: the inert waste, which comprises mainly sand, bricks, blocks, steel, concrete debris, tiles, bamboo, plastics, glass, wood, paper, and other organic materials (Nagapan et al., 2012b; Ma, 2011; Saidu and Shakantu, 2016a). This type of waste could either be recovered through recycling or re-use of some of its constituents; or completely lost due to the fact that they may be irreparably damaged or simply stolen. The wastage is usually removed from the site to landfills (Nagapan et al., 2012b; Saidu and Shakantu, 2015; Saidu, 2016).

\subsubsection{Non-Physical Construction Waste}

The non-physical waste normally occurs during the construction process. In contrast to the physical or material waste, non-physical waste relates to time overruns and cost overruns for construction projects (Nagapan et al., 2012b; Saidu, 2016). Similarly, Ma (2011) defines waste as not only associated with wastage of materials, but also to other activities such as delays due to repair, waiting time, among others. Besides that, waste can be considered as any inefficiency that results in the use of equipment, materials, labour, and money in the construction process (Ma, 2011). In other words, waste in construction is not only focused on the quantity of materials wasted on site, but also covers issues like overproduction, waiting time, material handling, inventories, and unnecessary movement of workers (Nagapan et al., 2012a).

\subsection{Construction Cost Overrun}

Cost overruns are part of the non-physical waste that have plagued construction projects for decades or even centuries (Edward, 2009). Cost overrun is also known as "cost increase" or "budget overrun"; and it involves unanticipated costs incurred in excess of the budgeted amounts (Shanmugapriya and Subramanian, 2013). It has also been referred to as the percentage of actual or final costs above the estimated or tender costs of the project (Ubani et al., 2011; Jenpanistub, 2011). Azhar et al. (2008) view cost overrun simply as an occurrence, where the final or actual cost of a project surpasses the original or initial estimates. It is the actual or final costs, minus the estimated cost, divided by the estimated/tender costs of a 
project expressed as a percentage (Memon, 2013; Ubani et al., 2011) This is represented mathematically:

Cost Overrun $=\frac{\text { Actual Cost-Estimated Cost }}{\text { Estimated } \text { Cost }} X 100$

The actual costs are referred to as the real and accounted construction costs realised at the completion of a project; while the estimated costs are the budgeted, estimated or forecasted construction costs determined at the inception of projects after the actual design has been developed (Ubani et al., 2011; Memon, 2013). Nega (2008) defines cost overrun as an occurrence, in which the delivery of contracted goods/services is claimed to require more financial resources than was originally agreed upon between a project sponsor and a contractor.

\subsection{Causes of Cost Overruns}

Cost overruns in the construction industry have been attributed to a number of causes, including technical errors in design or estimation, managerial incompetence, risks and uncertainties, suspicions of foul play, deception and delusion, and even corruption (Ahiaga-Dagbui and Smoth, 2014). The two main causes of cost overruns in a project, according to Flyvbjerg, Holm and Buhl (2004) are: optimism bias and strategic misrepresentations. Optimism bias summarises the systematic tendency of decision-makers to be more positive about the results of planned actions; whereas strategic misrepresentations have to do with confusing or misleading actions used by planners in politics and economics, to ensure that projects proceed. Furthermore, other surveys have identified the four major factors that cause cost overruns for a project are: variations in design, insufficient project planning, inclement weather conditions, and building materials' price fluctuation (Allahaim and Liu 2012).

In another study, the top five (5) important causes of cost overruns in large projects in Vietnam were: poor site management and supervision, poor subcontractors and project management assistants, owners' financial constraints, contractors' financial difficulties, and changes in design (Le-Hoai et el., 2008).

Al-Najjar (2008) investigated the causes of cost overruns in the Gaza strip, and found that fluctuations in the prices of construction materials, as a result of border closure, was the major cause of cost overruns. Other factors were: delays in the delivery of materials and equipment to site, and inflation of the prices of materials. In another study, Subramani et el. (2014) surveyed the causes of cost overruns in India. The results indicated that, slow decision-making at the planning stage of a project, poor project schedules and management, increases in the prices of materials and machines, poor contract management, poor design, delay in producing design, rework due to mistakes, land-acquisition problems, poor estimation or estimation techniques, and the long-time taken between the design and the time of bidding/tendering are the major causes of cost overruns.

Aziz (2013) examined the factors causing cost overruns in waste-water projects in Egypt, and concluded that lowest tendering procurement method, additional works, bureaucracy in tendering methods, wrong cost-estimation methods, and funding problems by client were the major causes of cost overruns.

Shanmugapriya and Subramanian (2013) identified 54 causes of cost overruns and categorised them in to six (6) major groups, namely: financial group (the fluctuating exchange rate, and the lack of sound financial management and planning); construction items group (mistakes during construction, wastages on-site, inadequate design, the lack of co-ordination at design stage, and the rework needed due to mistakes or errors); political group (difficulties in importing equipment and materials); materials group (changes in materials specifications, material price increases, and material shortage); labour and equipment group (the high cost of machinery, high maintenance costs of machinery, frequent breakdown of the construction plant and equipment, and high transportation costs); and owner's responsibility group (additional work by clients, and the high quality of work required).

Ameh et al. (2010) examined the significant factors causing cost overruns in the telecommunication projects in Nigeria. The results revealed the following: lack of experience by the contractor, the high cost of importing materials, and the materials' price fluctuation. In another study, Ejaz et al. (2011) discovered that increases in material prices, poor project control techniques, shortage of technical personnel, delays in work approval, and the shortage of materials and plant/equipment are the major causes of cost overruns in Pakistan.

Baloyi and Bekker (2011) conducted a study on the causes of cost overruns in the 2010 FIFA world cup stadia in South Africa. The result revealed that project complexity, increases in labour costs, inaccurate quantity estimations, differences between the selected bid and the consultants' estimates, variation orders by clients during construction, and manpower shortage were the main causes of cost overruns.

Kaliba et al. (2009) concluded that the problem of cost overruns in Zambia were caused by inclement weather conditions, changes in the size of projects, the cost of environmental sustainability, delays in the work programme, civil unrest, technical constraints, and increases in material prices.

Omoregie and Radford (2006) examined the causes of cost overruns in the infrastructural projects in Nigeria. The result revealed the major causes as: fluctuations in material prices, financing and payments made for completed works, inefficient contract management, delays in scheduling, variations in site condition, inaccurate cost estimates, and material shortages. In another study, Kasimu (2012) found that fluctuations in materials prices, insufficient time, lack of experience in contracts works, and incomplete drawings were the major causes of cost overruns in building construction projects in Nigeria.

Malumfashi and Shuaibu (2012) conducted a study on the causes of cost overruns in the infrastructural projects 
in Nigeria. The results revealed the major causes as improper planning, material-price fluctuations, and inadequate finance from the project's inception.

\subsection{Construction-Material Waste and Cost Overrun}

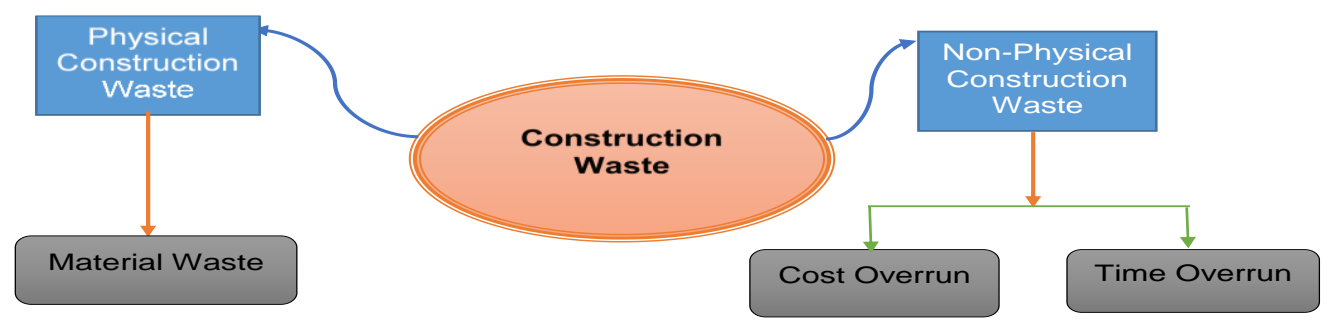

Figure 1: Classification of Construction Waste

Moreover, research evidence revealed that material waste accounts for additional percentage of cost overrun in countries like the UK, Hong Kong, Netherlands, Nigeria and so forth (Ameh and Itodo, 2013; Saidu and Shakantu, 2015; Saidu and Shakantu, 2016a; Saidu, 2016). For instance, Tam et al. (2007 in Ameh and Itodo, 2013) reported that, in the UK, material waste accounts for an additional $15 \%$ of construction project cost overruns and for approximately $11 \%$ of construction cost overruns in Hong Kong. Similarly, a study conducted in the Netherlands revealed a cost overrun of between $20 \%$ and $30 \%$ as a result of construction-material wastage (Bossink and Bounwers, 1996). However, the methodologies adopted to achieve these contributions of material waste to cost overruns are based on surveys and considered a subjective assessment. Nonetheless, these studies have failed to objectively (quantitatively and empirically) address the contributions of material waste to project cost overruns, because of wrong perceptions and this calls for actual data such as on-site observation and records (Saidu and Shakantu, 2016b). It was on this basis that Saidu and Shakantu (2016b) carried out an objective assessment of the contributions of material waste to cost overruns in Abuja, Nigeria. The results revealed that material waste contributes an average of $4.0 \%$ to project cost overruns for the entire projects.

\section{Research Methodology}

This research covers building construction projects within Abuja, the Federal Capital Territory of Nigeria. Abuja was selected because it is one of the metropolitan cities of Nigeria that has the highest population of professionals within the built environment and has many on-going construction projects. Primary data were generated from interviews conducted with thirty (30) construction professionals within Abuja. The interviews were conducted using purposive sampling techniques. It is purposive, because only building-construction professionals handling projects worth 1.6 billion Naira (8 million USD) and above were consulted/interviewed. Projects of 8 million USD and above are likely to be handled by more experienced professionals, who might be more familiar with the issues leading to material waste and cost overrun than the projects of less value.
Construction waste entails both the physical and the nonphysical waste, therefore, there is a nexus between material waste originating from the physical waste and cost overrun from the non-physical waste, since they both originate from the same waste family (Saidu and Shakantu, 2016a). This classification is shown in Figure 1
Furthermore, Leedy and Ormrod (2014) believed that the size of interviews using a purposive sampling technique ranges between 5 and 25 participants. The thirty (30) professionals interviewed in this research included: 15 Project Managers (PMs), 9 Quantity Surveyors (QSs), 5 Site Engineers (SEs), and 1 Senior Technical Officer (STO) of a construction-waste management department. The interviews were on the issues relating to material waste and cost overruns at the pre-contract and at the postcontract stages of a construction project.

An interview guide was used to collect empirical data. The interviews were conducted in order to solicit the opinions of construction professionals on the causes of material waste that relate to causes of cost overruns. The semi-structured but in depth interview guide assisted the researchers. The interview guide was structured in two major group namely: pre-contract and post-contract stages of a project. Probing questions were asked during discussion with the interviewees in order to obtain further information. An average of thirty-five (35) minutes was spent in conducting each interview.

All the thirty (30) respondents identified in this research through the purposive sampling method responded to all the questions presented for discussion. Moreover, the application of the inductive analysis of data in qualitative research enabled the researchers to extensively condense raw data into brief and summary format, and to establish clear links between the research purpose and the summary findings derived from raw data. The recorded, transcribed and interpreted interview data were analysed by using the deductive approach, which involves constant comparative analysis of the data, after it has been sorted and coded to generate knowledge about any common pattern within the interviewees' evidence on material waste and cost overrun. The analysis began by comparing the opinions made by the first two interviewees. The process continued with a comparison of the data from the comments and inputs from each new interviewee, until all the responses had been compared with each other. The similarities and differences among the interviewees' responses were used to develop a conceptualisation of the possible relationship between the various data items. 
The interviews result which are composed in themes are therefore, summarised in Table 3 and Table 4 of this research.

\section{Research Findings}

\subsection{Findings from Secondary Data (Literature Review)}

This section presents the research results identified from the literature review.

\subsubsection{Relationship between Material Waste and Cost Overrun at Pre-Contract Stage of a Project}

Table 1 reveals that most of the causes of material waste and those of cost overruns identified from the literature are the same. All the causes of material waste were also identified as the causes of cost overrun at the pre-contact stage of a project but not vice versa. For instance, 31 out of the 32 causes of cost overruns considered at the precontract stage of a project were also found to cause material waste, which indicate a $96.88 \%$ relationship (precontract stage). The only cause of material waste not linked to cause of cost overrun was 'the practice of assigning the contract to the lowest bidder'. This means that all causes of material waste also cause anticipated cost overrun at the pre-contract stage of a project. But only $96.88 \%$ of the causes of cost overrun cause material waste. The remaining $3.12 \%$ is not related. This implies that, managing the causes of material waste at this stage denotes managing a $96.88 \%$ of the causes of cost overruns.

\subsubsection{Relationship between Material Waste and Cost Overrun at Post-Contract Stage of a Project}

Table 2 shows the causes of cost overrun that are related to the causes of material waste at the post-contract stage of a project. Out of the 66 causes of cost overruns considered, 54 also cause material waste showing an $81.81 \%$ relationship at the post-contract stage of a project. This shows that, at the post-contract stage of a project, all material waste causes are also responsible for the causes of cost overruns. But on the other hand, when causes of cost overruns are considered, there is an $81.81 \%$ relationship with causes of material waste. The remaining $18.19 \%$ are not related and are mostly, the micro and macro-economic factors. This implies that managing material waste at this stage denotes managing $81.81 \%$ of cost overruns.

The material waste causes that are marked with the sign $(\mathrm{X})$ are not found in the causes of cost overrun and therefore, labelled as not related to cost overrun.

Table 1. Causes of material waste related to causes of cost overruns at the pre-contract stage.

\begin{tabular}{|c|c|c|c|}
\hline Sn & $\begin{array}{c}\text { Causes of Cost } \\
\text { overrun }\end{array}$ & $\begin{array}{c}\text { Cost } \\
\text { overrun }\end{array}$ & $\begin{array}{l}\text { Material } \\
\text { waste }\end{array}$ \\
\hline 1 & Design error & $\checkmark$ & $\checkmark$ \\
\hline 2 & $\begin{array}{l}\text { Deficiencies in cost } \\
\text { estimates }\end{array}$ & $\checkmark$ & $\checkmark$ \\
\hline
\end{tabular}

Insufficient time for estimate

Improper planning at on stage

Political complexities

6 Insurance problems

7 Changes in material specification

8 Laws and regulatory framework

9 Lack of experience of local regulation

$10 \quad$ Practice of assigning contract to the lowest bidder

11 Poor communication flow among design team

12 Communication error amongst parties in planning

13 Poor knowledge of the changing requirements

14 Lack of design information

15 Designing irregular shapes and forms

16 Different methods used in estimation

17 Improper coordination

18 Delays in design

19 Optimism bias

20 Complicated design

21 Inadequate specifications

22 Incomplete drawings

23 Error in design and detailing

24 Poor design management

25 Inadequate site investigation

26 Difficulties in interpreting specification

27 Delay in preparation and approval of drawings

28 Designing uneconomical shapes and outlines

29 Frequent demand for design changes

30 Inexperienced designer

31 Unsatisfactory budget for waste management

32 Lack of communication among parties at precontract stage
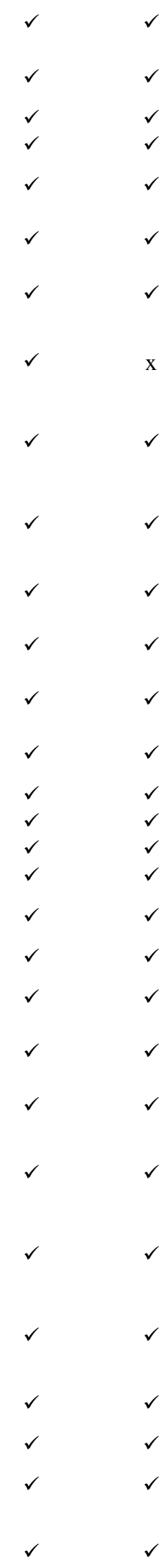

Summary $=31 / 32 X 100=96.88 \%$ 
Table 2. Causes of material waste related to causes of cost overrun from literature

\begin{tabular}{|c|c|c|c|}
\hline Sn & $\begin{array}{c}\text { Causes of Cost overrun } \\
\text { (post-contract) }\end{array}$ & $\begin{array}{c}\text { Cost } \\
\text { overrun }\end{array}$ & $\begin{array}{l}\text { Material } \\
\text { waste }\end{array}$ \\
\hline 1 & $\begin{array}{ll}\text { Monthly } & \text { payment } \\
\text { difficulties } & \end{array}$ & $\checkmark$ & $\mathrm{x}$ \\
\hline \multirow[t]{2}{*}{2} & $\begin{array}{l}\text { Poor planning by } \\
\text { contractors }\end{array}$ & $\checkmark$ & $\checkmark$ \\
\hline & $\begin{array}{l}\text { Discovery of heritage } \\
\text { materials to replace } \\
\text { imported ones }\end{array}$ & $\checkmark$ & $\checkmark$ \\
\hline 4 & Market conditions & $\checkmark$ & $\mathrm{x}$ \\
\hline 5 & $\begin{array}{l}\text { Cash flow and financial } \\
\text { difficulties faced by } \\
\text { contractors }\end{array}$ & $\checkmark$ & $\mathrm{x}$ \\
\hline 6 & $\begin{array}{l}\text { Slow information flow } \\
\text { between the parties }\end{array}$ & $\checkmark$ & $\checkmark$ \\
\hline 7 & $\begin{array}{l}\text { Escalation of material } \\
\text { prices }\end{array}$ & $\checkmark$ & $\mathrm{x}$ \\
\hline 8 & Increase in wages & $\checkmark$ & $\mathrm{x}$ \\
\hline 9 & $\begin{array}{l}\text { Poor site management and } \\
\text { supervision }\end{array}$ & $\checkmark$ & $\checkmark$ \\
\hline 10 & Exchange rate fluctuation & $\checkmark$ & $\mathrm{x}$ \\
\hline 11 & $\begin{array}{l}\text { Deficiencies in the social } \\
\text { structure }\end{array}$ & $\checkmark$ & $\checkmark$ \\
\hline 12 & Optimism bias & $\checkmark$ & $\checkmark$ \\
\hline 13 & $\begin{array}{l}\text { Labour cost increases due } \\
\text { to environment restriction }\end{array}$ & $\checkmark$ & $\mathbf{x}$ \\
\hline 14 & Insufficient equipment & $\checkmark$ & $\checkmark$ \\
\hline 15 & $\begin{array}{l}\text { Deficiencies in the } \\
\text { infrastructure }\end{array}$ & $\checkmark$ & $\checkmark$ \\
\hline 16 & $\begin{array}{l}\text { Lack of communication } \\
\text { among parties }\end{array}$ & $\checkmark$ & $\checkmark$ \\
\hline 17 & $\begin{array}{l}\text { Change in the scope of } \\
\text { work }\end{array}$ & $\checkmark$ & $\checkmark$ \\
\hline 18 & $\begin{array}{l}\text { Delay of payment to } \\
\text { supplier/subcontractors }\end{array}$ & $\checkmark$ & $\checkmark$ \\
\hline 19 & Shortage of materials & $\checkmark$ & $\checkmark$ \\
\hline 20 & On-site waste & $\checkmark$ & $\checkmark$ \\
\hline 21 & Project size & $\checkmark$ & $\checkmark$ \\
\hline 22 & Lack of constructability & $\checkmark$ & $\checkmark$ \\
\hline 23 & $\begin{array}{l}\text { Unrealistic contract } \\
\text { duration }\end{array}$ & $\checkmark$ & $\checkmark$ \\
\hline 24 & $\begin{array}{l}\text { Delay in material } \\
\text { procurement }\end{array}$ & $\checkmark$ & $\checkmark$ \\
\hline 25 & Inexperienced contractor & $\checkmark$ & $\checkmark$ \\
\hline 26 & Shortage of site workers & $\checkmark$ & $\checkmark$ \\
\hline 27 & Work security problems & $\checkmark$ & $\checkmark$ \\
\hline 28 & Re-work & $\checkmark$ & $\checkmark$ \\
\hline
\end{tabular}

4.1.3 Summary of the Relationships at the Pre-Contract and Post-Contract Stages of a Project
29 Experience in contracts

30 Workers health problems

31 Unexpected subsoil conditions

32 Poor geological surveys

33 Financial difficulties of contractor

34 Social and cultural impact

35 Inaccurate site investigation

36 Inadequate use of modern equipment \& technology

37 Obtaining materials at official current prices

38 Labour problems

39 Increase in material prices

40 Owner interference

41 Slow payment of works

42 High interest rate charged by banks on loans

43 Fraudulent practices

44 Labour disputes and strike

45 Improper coordination amongst parties at post contract stage

46 Poor technical performance

47 Equipment availability/failure

48 Number of works being done at same time

49 Poor financial control on site

50 Poor site management and supervision

51 Site constraints

52 Lack of skilled labour

53 Mistakes during construction

54 Delay in decision making

55 Late materials/equipment delivery

56 Unpredictable weather condition

57 Unforeseen site conditions

58 Management-labour relationship

59 Inexperience of project location

Summary $=48 / 59 X 100=81.36 \%$

Summing all the causes at both the pre-contract and the post-contract stages, $32+59=91$, a total of 79 out of 98 causes of cost overruns also cause material waste showing $79 / 91 X 100=86.81 \%$ relationship. These findings are also graphically represented in Figure 2 


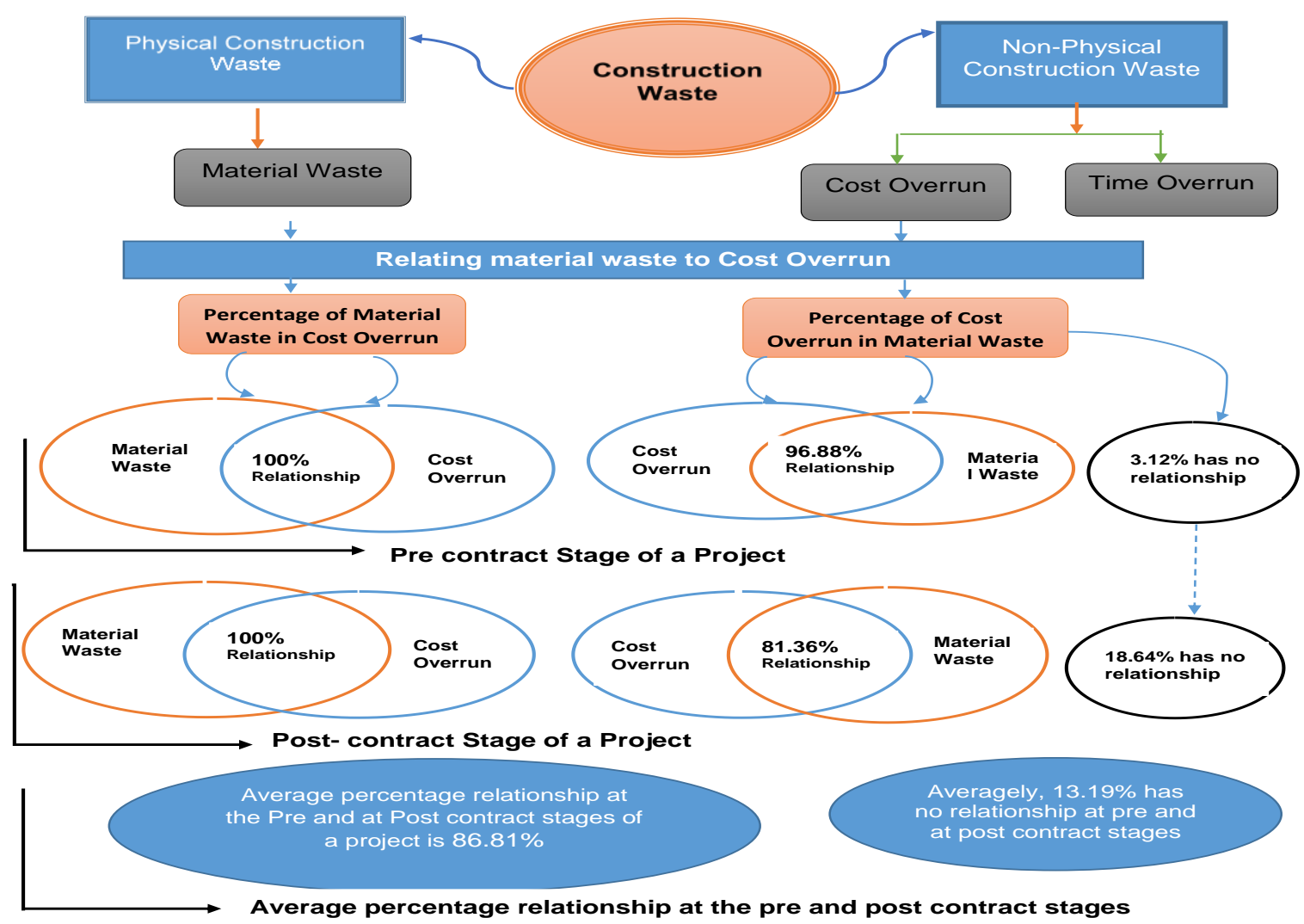

Figure 2. Relationship between material waste and cost overrun at all stages of a project

It can therefore be concluded that the relationship between causes of material-waste and causes of cost overruns is $86.81 \%$. Though, this result is not the actual contribution of material waste to cost overrun, but a relationship between their causes (material waste and cost overruns). The actual contribution of material waste to cost overrun could vary from site to site and from different geographical locations.

\subsection{Findings from Primary Data (Interview)}

This section presents the research findings identified from interview session with the respondent.

4.2.1 Material Waste Causes Related to Causes of Cost Overruns at the Pre-Contract and Post Contract Stages of a Project

Table 3 summarises the results of the interviews conducted with construction professionals on the causes of material waste that are related to the causes of cost overruns at pre-contract and pot-contract stages of a project.

\begin{tabular}{|c|c|c|c|}
\hline Sn & $\begin{array}{l}\text { Material waste causes that relate to causes of cost } \\
\text { overruns at the pre-contract stage of a project }\end{array}$ & Sn & $\begin{array}{c}\text { Material waste causes that relate to causes of } \\
\text { cost overruns at the post-contract stage of a } \\
\text { project }\end{array}$ \\
\hline & Planning phase & & Site management phase \\
\hline 1 & Improper planning & & Storage source \\
\hline 2 & Lack of feasibility and viability studies & 1 & Wrong material/equipment storage/stacking \\
\hline 3 & Lack of legislative enforcement & 2 & $\begin{array}{l}\text { Wrong materials handling from storage to } \\
\text { application }\end{array}$ \\
\hline 4 & Inadequate site investigation & 3 & Damage by other trades \\
\hline 5 & Inadequate scheduling & 4 & Poor site storage area \\
\hline 6 & Poor communication flow among members & 5 & Long storage distance from application point \\
\hline 7 & Improper coordination of the entire project & 6 & Damage by weather \\
\hline 8 & Unsatisfactory budget for waste management & & Security source \\
\hline 9 & Insurance problem & 7 & Inadequate site security/Fencing \\
\hline 10 & Poor plan for material standardization & 8 & Theft \\
\hline 11 & Inadequate plan for waste management unit & 9 & $\begin{array}{l}\text { Vandalism, sabotage pilferage, and material } \\
\text { damage }\end{array}$ \\
\hline 12 & Improper plan for material waste re-use $\&$ disposal & 10 & Power and lighting problems on site \\
\hline
\end{tabular}


Improper program of work

Improper plan for site organization and layout

Lack of regular site meetings

Compliance with local authority in case of local laws

Improper planning and understanding of method statement

Improper planning of project risks

Lack of inclusion of waste management in bidding process

Improper plan for the establishment of a quality control unit

Inexperienced personnel in planning

Improper plan for record of material inventory

Poor harmonization of brief

Poor knowledge of site conditions

Cost related problems

Inadequate identification of construction techniques

Poor material estimation

Communication error between client and designer

Frequent demand for design change

\section{Design phase}

Frequent design changes and material specification

Error in design and detailing

Lack of design information

Design complexity / complication

Poor communication flow among design team

Designing dead spaces

Poor knowledge of the changing design requirements Poor management of design process

Inexperience designer / design team

Interaction between various specialists

Designing uneconomical shapes and outlines

Lack of standardization in design/ sizes and units

Lack of buildability analysis

Difficulty in interpreting material specifications

Readability, constructability and maintainability

\section{Insufficient time for design}

Poor harmonization of client's brief

Over or under designing

Aesthetic considerations

Poor planning of design process

Poor design functionality

Designing unavailable technology

Lack of geo-physical survey

\section{Estimating phase}

Over/under estimating

Inaccurate quantity take-off

Insufficient time for estimate

Different estimation methods

Inexperienced estimator

Lack of detailed drawing and specifications (readable and interpretable)

\section{Site conditions}

11 Lack of adherence to program of work

12 Leftover materials on site

13 Waste resulting from packaging

14 Lack of environmental awareness

15 Difficulties in accessing construction site

16 Problems relating to on-site health and safety

17 Wrong placement of equipment on site

18 Site accidents

19 Late delivery of materials

\section{Operation source}

20 Lack of quality control

21 Lack of waste management plans

22 Non-availability of appropriate equipment

23 Wrong placement of equipment on site

24 Communication problems

25 Late information flow among parties

26 Lack of co-ordination among parties

27 Poor construction planning and control

28 Poor site supervision

29 Rework

30 Inappropriate records of materials

31 Lack/poor adherence to material waste regulations

32 Inappropriate delegation of responsibilities

33 Lack of experience

34 Site accidents

35 Material procurement and transp

36 Procuring items not in compliance with specification

37 Errors in shipping

38 Mistakes in quantity surveys: Poor estimate for procurement

39 Wrong material delivery procedures

40 Delivery of substandard materials

41 Damage of material during transportation

42 Inadequate delivery schedule

43 Poor market conditions

44 Poor material handling

45 Waiting for replacement

46 Poor protection of materials and damage during transportation

47 Over allowance

48 Frequent variation orders

49 Poor product knowledge

50 Procuring wrong quantity of materials at the wrong time

51 Inexperienced personnel in estimation and procurement

52 Procuring substandard materials

53 Difficulties of vehicles in accessing site

54 Lack of quality control assurance for evaluation of procured product

55 Lack of professionalism and transparency in procurement 
Inadequate project risks evaluation, analysis, and estimation

61 Inadequate knowledge of site conditions

62 Lack of estimating information

63 Poor knowledge of fluctuating market conditions/prices

64 Frequent design change

65 Late engagement of estimators
56 Competent procurement management

\subsubsection{Managing Material Waste and Cost Overrun}

In order to effectively manage material waste and cost overruns on construction sites, the material waste control measures that have effects in controlling cost overruns at both pre-contract and post-contract stages of a project must be put in place. The material waste control measures that have effects on cost overruns were identified and summarised from the interview session with the respondents. These are presented in Table 4.

Table 4. Material waste control measures that have effects in controlling cost overruns at the pre-contract and at the post contract stages of a project

\begin{tabular}{|c|c|c|c|}
\hline Sn & $\begin{array}{c}\text { Material waste control measures that have } \\
\text { effects in controlling cost overruns at the pre- } \\
\text { contract stage of a project }\end{array}$ & Sn & $\begin{array}{c}\text { Material waste control measures that have } \\
\text { effects in controlling cost overruns at the post- } \\
\text { contract stage of a project }\end{array}$ \\
\hline 1 & Plan for early sub-soil investigations & 1 & Better transportation of materials \\
\hline 2 & $\begin{array}{l}\text { Plan for inclusion of waste management in bidding } \\
\text { and tendering processes }\end{array}$ & 2 & $\begin{array}{l}\text { Efficient methods of unloading materials supplied } \\
\text { in loose form }\end{array}$ \\
\hline 3 & Proper planning of construction projects layout & 3 & Adopting good materials abstracting \\
\hline 4 & Proper investment into waste reduction & 4 & Provision of easy access road for vehicles delivery \\
\hline 5 & $\begin{array}{l}\text { Proper coordination and communication at pre- } \\
\text { contract stage of a project }\end{array}$ & 5 & $\begin{array}{l}\text { Adoption of unified method of estimating for } \\
\text { procurement process }\end{array}$ \\
\hline 6 & Improved planning and scheduling & 6 & $\begin{array}{l}\text { Ordering appropriate materials quantity and timely } \\
\text { delivery of materials }\end{array}$ \\
\hline 7 & $\begin{array}{l}\text { Execute a plan that will reduce frequent design } \\
\text { change }\end{array}$ & 7 & $\begin{array}{l}\text { Tight security, workable security lighting, and } \\
\text { adequate site temporary fencing }\end{array}$ \\
\hline 8 & $\begin{array}{l}\text { Enhance regulation execution of related } \\
\text { government departments and legislative } \\
\text { enforcement }\end{array}$ & 8 & $\begin{array}{l}\text { Integration of waste management into the } \\
\text { assessment of construction contractor }\end{array}$ \\
\hline 9 & Set a target for material waste reduction & 9 & Procuring in accordance with specification \\
\hline 10 & Ensure adequate geophysical surveys & 10 & $\begin{array}{l}\text { Experienced personnel in estimation and } \\
\text { procurement }\end{array}$ \\
\hline 11 & Proper insurance of works & 11 & Insurance of the procured materials \\
\hline 12 & Plan for material standardisation & 12 & Recycle generated waste materials \\
\hline 13 & $\begin{array}{l}\text { Re-improving process (monitoring / learning from } \\
\text { previous mistakes and improving on them) }\end{array}$ & 13 & $\begin{array}{l}\text { Formation of a quality control unit for evaluation of } \\
\text { procured product }\end{array}$ \\
\hline 14 & Regular site meetings & 14 & Competent procurement management \\
\hline 15 & Establishment of good waste management unit & 15 & Professionalism and transparency in procurement \\
\hline 16 & Carrying design team along & 16 & Materials manufactured in standard units \\
\hline 17 & Adequate material waste estimation & 17 & Knowledge of product to be manufactured \\
\hline 18 & Planning of project risks & 18 & Better and improved supply chain management \\
\hline 19 & Communication and coordination of design process & 19 & Adequate site organization and discipline \\
\hline 20 & $\begin{array}{l}\text { Consideration of available technology, resources } \\
\text { and materials }\end{array}$ & 20 & $\begin{array}{l}\text { Proper administration of } 5 \mathrm{Ms} \text { (men, material, } \\
\text { money, machines and management) on site }\end{array}$ \\
\hline 21 & Identification of construction technique & 21 & Proper scheduling and planning \\
\hline 22 & Performance of feasibility and Viability studies & 22 & Use of skilled and experienced labour \\
\hline 23 & Performing a buildability analysis & 23 & Adequate site control and supervision \\
\hline 24 & Proper harmonization of brief & 24 & Competent supplier \\
\hline 25 & $\begin{array}{l}\text { Improve major project stakeholders' awareness on } \\
\text { resource saving \& environmental protection }\end{array}$ & 25 & $\begin{array}{l}\text { Research and development in the discipline of } \\
\text { waste management }\end{array}$ \\
\hline 26 & $\begin{array}{l}\text { A design recommending available human resources } \\
\text { and local materials }\end{array}$ & 26 & $\begin{array}{l}\text { Proper records and documentation of } \\
\text { materials/daily record taking and materials request } \\
\text { booklets. }\end{array}$ \\
\hline 27 & Design for materials optimization & 27 & $\begin{array}{l}\text { Improve contractors' onsite construction } \\
\text { management }\end{array}$ \\
\hline
\end{tabular}


28 Design for reuse and recovery

29 Design for offsite construction

30 Designing for deconstruction

31 Designing economic shapes and outlines

32 Use of prefabricated units and standard materials

33 Interaction between different designers (Architects and Engineer)

34 Utilization modular designs

35 Reduced design complexity

36 Explicit detailing in design

37 Interpretable design and specifications

38 Experienced designer

39 Proper management of design process

40 Error-free design

41 Proper monitoring and supervision of work

42 Readable dimensions and specifications

43 Proper design information and consultation

44 Adherence to clients' brief

45 Sufficient time for design

46 Early engagement of designer

47 Experienced personnel in planning
28 Appropriate material storage

29 Proper communication \& coordination on site

30 Error-free construction process

31 Process improvement techniques

32 Adequate building technique

33 Establish systems of rewards and punishments for material saving

34 Proper management workers support

35 Awareness among practitioners on managing waste

36 Staff vocational training

37 Ensuring that good quality workmanship is achieved

38 Appropriate material utilization

39 Availability of good work-life balance

40 Engaging competent workers

41 Adherence to specifications

42 Regular site meetings

43 Better storage facilities and environment/area

44 Improved method of material usage

45 Standard evaluation and comparing with specification

46 Proper material protection against weather

47 Adherence to design and specifications

48 Adherence to waste management regulations and waste management throughout the entire project lifecycle

49 On-site and offsite re-use of waste, separation of hazardous waste and on-site waste sorting
To achieve Effective Construction Material Waste Management (ECMWM) in any construction project, material waste must be controlled at its sources and causes and at different stages of a project. This will in turn control a coefficient of cost overrun for that project (Saidu and Shakantu, 2016a). To accomplish this, Figures 3 and 4 show the interrelationship between project stages (precontract and post-contract), ECMWM, material-waste sources, material-waste causes and the percentage coefficient of cost overrun.

Figure 4 shows that, unless construction-material waste control (ECMWM in Table 3) is tight at all sources and causes of material waste and at the stages of a project otherwise, cost overrun is bound to occur.

For example, as shown in Figure 3, if control is loose at the stages of a project (pre-contract / post-contract) or at material waste sources / causes, the project may likely overrun its initial budget by certain percentage. In Figure 3 the overrun is shown as a heavy weight in red ink pulling down the project. Though, the overrun may not completely be occasioned by material waste alone, but by a coefficient /certain percentage while the other remaining percentage may be caused by other factors, such as macro and micro economic variables and so forth (Saidu and Shakantu, 2016a).

The information in Figure 3 is further represented in Figure 4 (VENN diagram of SET theory in mathematics) showing the interrelationships and intersections between material waste causes, material waste sources, coefficient of cost overrun, project stages, and ECMWM. As stated earlier, the cost overrun must be a coefficient (a percentage), because it cannot be completely caused by material waste in a complete project. Figure 4 shows how ECMWM could be utilised through a simple mathematics equation to eliminate the likely coefficient of cost overrun for a project. To achieve this, three thin lines were drawn from one end to the other in order to form a triangle within the three intersecting circles. The three lines ends were labelled $\mathrm{A}, \mathrm{B}$ and $\mathrm{C}$ with the running lines labelled as line 01, A-B; line 02, A-C; and line 03 B-C respectively. For instance, line 01 , A-B forms the hypotenuse of a rightangle triangle which is completed with doted lines meeting at the ECMWM. This will be used as one of the equations that would determine how the coefficient of cost overrun would be directly eliminated with a complete application of ECMWM in a project. The same applies to other lines (line 02, A-C and line 03, B-C). The assumption here is that, if waste management and control processes are completely applied $(100 \%)$ in a project, the coefficient of the cost overrun for that project can therefore be completely eliminated and vice versa. The coefficient of cost overrun identified from the literature (Figure 2, average percentage relationship between material waste and cost overrun) was 0.8681 . 


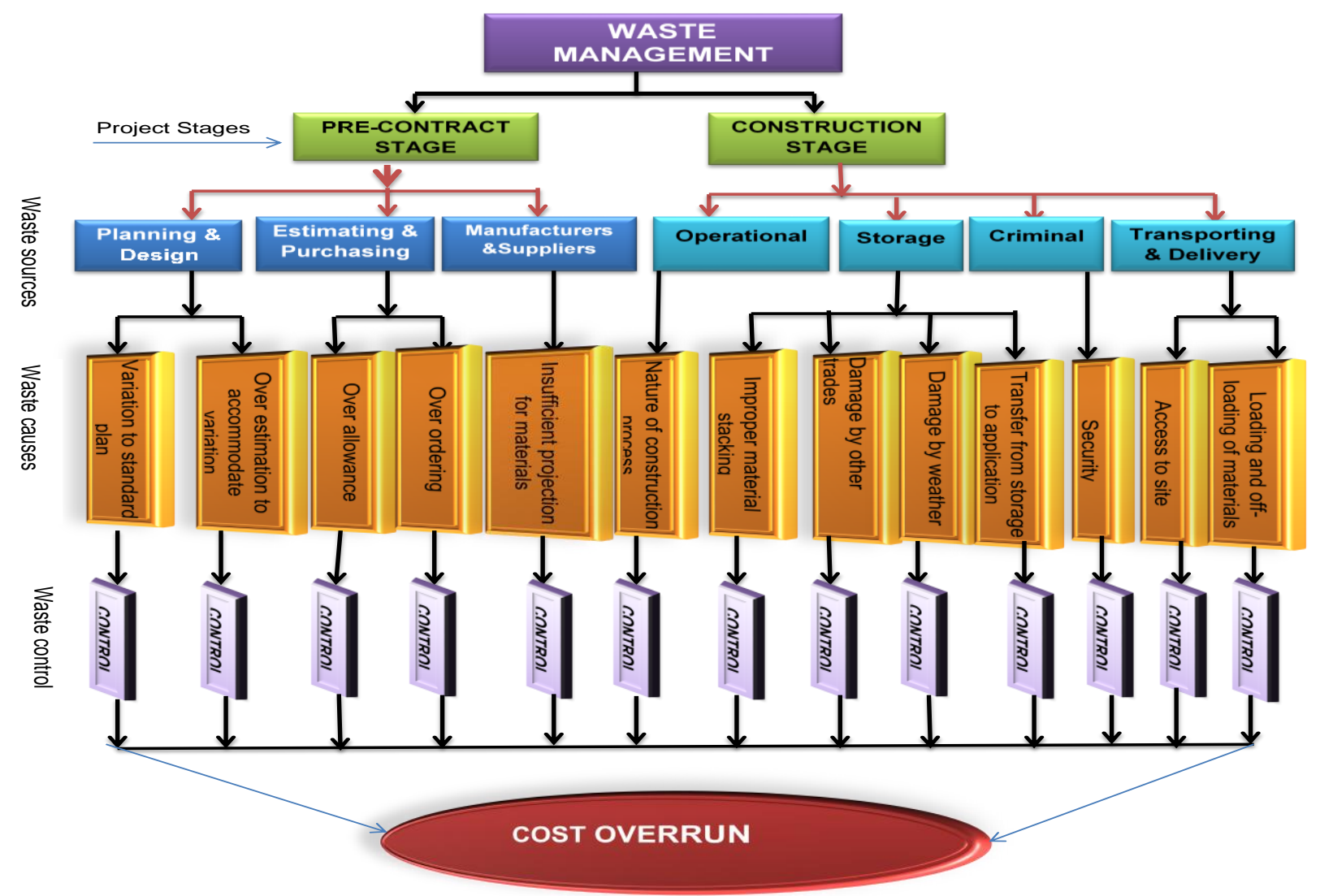

Figure 3. Summary of the relationship in Figure 2

This interrelationship is shown in Figure 4.

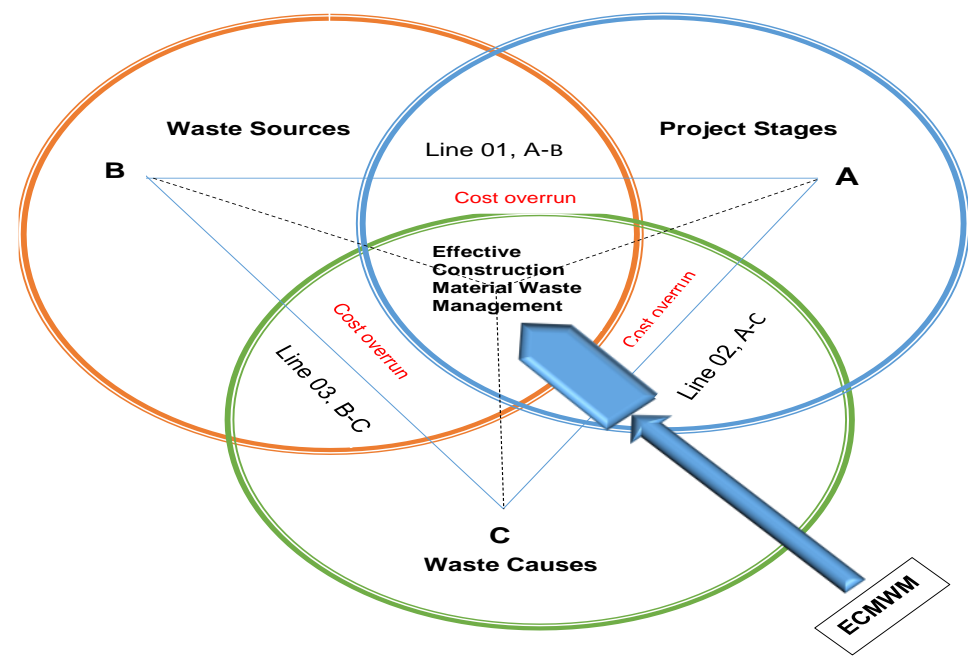

Figure 4: Relationship between project stages, waste sources, waste causes, management and cost overrun

This relationship is further represented mathematically showing how the coefficient of cost overrun is minimised/eliminated with Effective Construction Material Waste Management (ECMWM) from each scenario.

Line 01, A-B:
Considering line 01, A-B. This includes four (4) main issues namely: the project stages (A), waste sources (B), ECMWM (general intersecting point), and the coefficient of cost overrun (intersection between A and B) which is required to be minimised/eliminated.

The equation can be written as: 
This can be re-written as:

Project Stage + Waste Sources + ECMWM -0.87 Cost overrun $=0$

By making "ECMWM" the subject, it will change to positive (active) and the equation will be:

ECMWM = Project stage + Waste sources -0.87 Cost overrun

This means that active ECMWM at stages of projects (pre-contract and post-contract) and at sources of material waste would effectively minimise the cost overrun by 0.87 .

However, if ECMWM is negative (inactive) at project stages and waste source, then the coefficient of cost overrun must remain positive and active as shown in equation $01 \mathrm{~d}$.

0.87 Cost overrun $=$ Project Stage + Waste Sources - ECMWM

This is the same with other scenarios Line 02, A-C and

Line 03, B-C.

Line 02, A-C:

Project stage + waste causes $-E C M W M=0.87$ cost overrun

Project stage + waste causes -0.87 cost overrun $=E C M W M$

This means that effective management of waste causes at project stages would effectively minimise project cost overrun by 0.87 .
However, by making ECMWM inactive and negative, cost overrun will change and take over the positive position in a project as shown in equation $02 \mathrm{c}$.

0.87 Cost overrun $=$ Project Stage + Waste Causes - ECMWM

Line 03, B-C

Waste sources + waste causes $-E C M W M=0.87$ Cost overrun

Collecting the like terms by making "ECMWM" the subject, the equation will be:

Waste sources + waste causes -0.87 Cost overrun $=E C M W M$

Therefore, an "ECMWM" would minimise the occurrence of "cost overrun" by 0.87 . However, poor
"ECMWM" would lead to occurrence of "cost overrun" as shown in the equation below:

$-E C M W M=$ Project stage + Waste sources +0.87 cost overrun

Scenario 1 (Line 01, A-B), shows that waste sources within the project stage. Figure 6; cause an 4\% cost overrun. Therefore, to effectively control the project waste, there must be an Effective Construction Material Waste Management (ECMWM) at the project stages and at the waste sources, which will in turn, minimise cost overrun by 0.87 . The same applies to the remaining two other scenarios.

\subsection{Conclusions and Further Research}

Material waste and cost overrun are identified as global problems which affect the success of many construction projects. These are occasioned by several causes at different stages of projects. Identification of these causes at different stages and the application of relevant control measures to minimise their occurrence is a step towards alleviating the consequences. Moreover, most managers of construction projects pay little attention to the effects of waste generated on cost overrun. The aim of this research was to examine the relationship between the causes of material waste and those of cost overruns with a view to suggesting the possible ways of minimising their effects at the pre-contract and the post-contract stage of a project. The study reveals an average of $86.81 \%$ relationship between the causes of material waste and those of cost overruns at the pre-contract and postcontract stages of a project. $100 \%$ of the causes of material waste were found among the causes of cost overruns at the pre-contract and the post-contract stages of a project, while $96.88 \%$ and $81.36 \%$ of the causes of cost overruns cause material waste at the pre-contract and at the postcontract stages respectively. Other causes which are not related are mostly, the micro-economic and macroeconomic factors. It was also found that to achieve effective construction material waste management for any construction project, material waste must be controlled at its sources and causes, and at different stages of a project. 
Based on these findings, it can be concluded that effective management of material waste would translate into a reduction in the level of cost overrun by $86.81 \%$. The

\section{References}

Abdul-Rahman, I., Memon, A.H. and Abd. Karim, A.T. 2013. Significant Factors Causing Cost Overruns in Large Construction Projects in Malaysia. Journal of Applied Sciences, 13(2): 286-293.

Adewuyi, T. O. and Otali, M. 2013. Evaluation of Causes of Construction Material Waste: Case of River State, Nigeria. Ethiopian Journal of Environmental Studies and Management, 6: 746-753.

Ahiaga-Dagbui, D.D. and Smoth, S.D. 2014. Dealing with Construction Cost Overruns using Data Mining. Construction Management and Economics, 32 (7-8): 682694.

Al-Najjar, J.M. 2008. Factors Influencing Time and Cost Overruns on Construction Projects in the Gaza Strip. Masters Dissertation, Faculty of Engineering, the Islamic University of Gaza, 1-206.

Allahaim, F.S. and Liu, L. 2012. Cost Overrun Causes, the Framework in Infrastructure Projects: Toward a Typology. 37th Australian University Building Educators Association, International Conference (AUBEA, 2012) Sydney, University of NSW (UNSW), 1-15.

Ameh, O.J. and Itodo, E. D. 2013. Professionals' Views of Material Wastage on Construction Sites. Organization, Technology and Management in Construction. An International Journal, 5(1): 747-757.

Ameh, O.J. Soyingbe, A.A. and Odusami. K.T. 2010. Significant Factors Causing Cost Overruns in Telecommunication Projects in Nigeria. Journal of Construction in Developing Countries, 15 (2): 49-67.

Apolot, R. Alinaitwe, H. and Tindiwensi, D. 2010. An Investigation into the Causes of Delay and Cost Overrun in Uganda's Public Sector Construction Projects: Proceedings of the Second International Conference on Advances in Engineering and Technology, Uganda,

305-311.

Azhar, N. Farooqui, R.U. and Ahmed, S.M 2008. Cost Overrun Factors in Construction Industry of Pakistan. Proceedings of the First International Conference on Construction in Developing Countries (IC CIDC-I). Karachi, Pakistan. 499-508.

Aziz, R.F. 2013. Factors Causing Cost Variation for Constructing Waste Water Projects in Egypt. Alexandria Engineering Journal, 52: 51-66.

Baloyi, L. and Bekker, M. 2011. Causes of Construction Cost and Time Overruns: The 2010 FIFA World Cup Stadia in South Africa. Acta Structilia, 18 (1): 51-67.

Begum, R. A., Siwar, C. Pereira, J. J. and Jaafar, A. 2007. Implementation of Waste Management and Minimisation in the Construction Industry of Malaysia. Resources, Conservation and Recycling, 51: 190-202.

Bossink, B.A.G. and Brouwers, H. J.H. 1996. Construction Waste Quantification and Source Evaluation. ASCE Journal of Construction Engineering and Management, 122(1): 55-60.

Edward, C. 2009. Government Cost Overruns. CATO Institute, 2009. study recommends that management of material-waste causes should be encouraged, as it has the potential to minimise the causes of cost overrun for a project.

Ejaz, N. Ali, I. and Tahir, M.F. 2011. Assessment of Delays and Cost Overruns during Construction Projects in Pakistan. Viewed on 18 August 2015, http://www.civil.mrt.ac.lk/ICSECM 2011/SEC-1169.pdf.

Flyvbjerg, B. Holm, M.K. and Buhl, S.L. 2004. What Causes Cost Overrun in Transport Infrastructure Projects? Transport Reviews, 24 (1): 3-18.

Imam, A. Mohammed, B. Wilson, D.C. and Cheeseman, C.R. 2008. Country Report: Solid Waste Management in Abuja, Nigeria. Waste Management, 28: 468-472.

Jenpanitsub, A. 2011. Cost Overruns in Transport Projects - Experiences from Sweden. MSc Dissertation, Department of Transport science, KTH Royal Institute of Technology, Sweden, 1-127.

Kaliba, C., Muya, M. and Mumba, K. 2009. Cost Escalation and Schedule Delay in Road Construction Projects in Zambia. International Journal of Project Management, 27(5): 522-531.

Kasimu, M.A. 2012. Significant Factors that Cause Cost Overrun in Building Projects in Nigeria. Interdisciplinary Journal of Contemporary Research in Business, 3(11): 775-780.

Leedy, P.D. and Ormrod, J.E. 2014. Practical Research Planning and Design. Tenth Edition. Edited by Pearson new international Edition. Edinburgh Gate, England: Pearson Education Limited.

Le-Hoai, L. Lee, Y.D. and Lee, J.Y. 2008. Delay and Cost Overrun in Vietnam, Large Construction Projects: A Comparison with Other Selected Countries. KSCE Journal of Civil Engineering, 12(6): 367-377.

Lu, W. and Yuan, H. 2010. Exploring Critical Success Factors for Waste Management in Construction Projects of China. Resources, Conservation and Recycling, 55: 201-208.

Ma, U. 2011. No waste: Managing Sustainability in Construction. Surrey: Gower Publishing Limited.

Malumfashi, B.I. and Shuaibu, I. 2012. Risk Management and Cost Overrun in Infrastructure Projects in Nigeria. Journal of Environmental Sciences and Policy Evaluation, 2(2): 19-31.

Memon, A.H. 2013. The Way Forward in Sustainable Construction: Issues and Challenges. International Journal of Advances in Applied, 2 (1): 1-8.

Memon, A.H. Abdul-Rahman, I. Zainun, N.Y. and Abd-Karim, A.T. 2013. Web-based Risk Assessment Technique for Time and Cost Overrun (WRATTCO)-A Framework. Procedia-Social and Behavioural Sciences, 129: $178-185$.

Mou, K. 2008. The Role of Government and Construction Waste. MSc Dissertation, The Centre of Urban Planning \& Environmental Management, University of Hong Kong, Hong Kong: 1-179.

Nagapan, S. Abdul-Rahman, I. and Asmi, A. 2012a. Factors Contributing to Physical and Non-Physical Waste Generation in Construction Industry. International Journal of Advances in Applied Sciences (IJAAS), 1 (1): 1-10. 
Nagapan, S. Abdul-Rahman, I. Asmi, A. and Hameed, A. 2012b. Identifying the Causes of Construction WasteCase of Central. International Journal of Integrated Engineering, 4(2): 22-28.

Nega, F. 2008. Causes and Effects of Cost Overrun on Public Building Construction Projects in Ethiopia. MSc Dissertation, Department of Civil Engineering, Addis Ababa University Ethiopia.

Oladiran, O. J. 2009. Causes and Minimization Techniques of Materials Waste in Nigerian Construction Process. Fifth International Conference on Construction in the $21 \mathrm{st}$ Century (CITC-V); Collaboration and Integration in Engineering, Management and Technology, 20-22, May 2009, Istanbul, Turkey.

Omoregie, A. and Radford, D. 2006. Infrastructure Delays and Cost Escalation: Causes and Effects in Nigeria. Proceedings of the 6th International Conference on Postgraduate Research, April 3-7. Netherlands.

Osmani, M. 2011. Construction Waste. Chap. 15 in Waste: A Handbook for Management, by Letcher and Vallero, 1-565. San Diego: Academic Press.

Osmani, M. Glass, J. and Price, A.D.F. 2008. Architects' Perspectives on Construction Waste Reduction by Design. Waste Management, 28: 11471158.

Saidu, I. and Shakantu, W.M.W. 2015. A Relationship between Quality-of-Estimating, Construction Material Waste Generation and Cost Overrun in Abuja, Nigeria. Fourth Construction Management Conference, Nelson Mandela Metropolitan University, Port Elizabeth, South Africa. Emuze, F.A. (ed.); 95-104, 30 November-1st December, 2015.

Saidu, I. and Shakantu, W.M.W. 2016a. A Study of the Relationship between Material Waste and Cost Overrun in the Construction Industry. The 9th cidb Postgraduate Conference Cape Town, South Africa. "Emerging trends in construction organisational practices and project management knowledge area. Windapo, A.O. (ed.),124134, Feb, 2-4, 2016.

Saidu, I. and Shakantu, W.M.W. 2016b. A Conceptual Framework and a Mathematical Equation for Managing Construction-Material Waste and Cost Overruns. World Academy of Science, Engineering \& Technology. International Journal of Social Behavioural, Educational, Economic, Business and Industrial Engineering, 10 (2): 555-561.

Saidu, I. and Shakantu, W.MW. 2016c. The Contributions of Material Waste to Project Cost overrun in Abuja, Nigeria. Acta Structilia, 23 (1): 99-113.

Saidu, I. 2016. Management of Material Waste and Cost Overrun in the Nigerian Construction Industry. An Unpublished PhD Thesis, Department of Construction Management, Nelson Mandela Metropolitan University, Port Elizabeth, South Africa.

Shanmugapriya, S. and Subramanian, K. 2013. Investigation of Significant Factors Affecting Time and Cost Overrun in Indian Construction Projects. International Journal of Emerging Technology and Advanced Engineering, 3 (10): 734-740.

Subramani, T. Sruthi, P. S. and Kavitha, M. 2014. Causes of Cost Overrun in Construction. IOSR Journal of Engineering (IOSRJEN), 4 (6): 2278-8719.

Tam, V.W.Y. Shen, L.Y. Tam, C.M. 2007. Assessing the Levels of Material Wastage Affected by SubContracting Relationships and Projects Types with their Correlations. Building and Environment, 42: 1471-1477. Ubani, E.C. Okorocha, K.A. and Emeribe, S.C. 2011. Analysis of Factors Influencing Time and Cost overrun on Construction Projects in South Eastern Nigeria. International Journal of Management Sciences and Business Research, 2 (2): 73-84. 